\title{
Development Trends and Strategy Planning in Big Data Industry
}

\author{
Wei-Hsiu Weng \\ National Chengchi University \\ E-Mail: wh.weng@msa.hinet.net \\ Woo-Tsong Lin \\ National Chengchi University \\ E-Mail: lin@mis.nccu.edu.tw
}

\begin{abstract}
Big data refers to technology for storing, converting, transmitting, and analyzing large quantities of structured or unstructured data, which may be dynamic and diversified $\mathrm{d}$, for the purpose of social or commercial applications. Big data applications need to be able to undertake high-complexity and real-time analysis of vast amounts of data to help users make decision within the shortest possible timeframe. As a result, big data technology and the related industry are becoming ever more important. However, the scope, development trends, and possible strategy of big data industry have not been clearly addressed so far. To fill this gap, this paper presents a comprehensive assessment of the development trends and a systematic planning of business strategy in big data industry. The study utilizes nominal group technique (NGT), in-depth interviews, and focus group discussions among industry professionals. The research framework includes defining industry scope, assessing business environment by SWOT analysis, forecasting production value and growing trend, and outlining strategy for the emerging big data industry. The results provide a practical reference for vendors interested in entering the emerging big data market.
\end{abstract}

Keywords: Big data, Industry Development, Nominal Group Technique, SWOT, Strategy 


\section{INTRODUCTION}

Big data comes mainly from enterprise operational data warehouses, cloud computing data centers, shared information on social network websites and intelligent sensor networks. Taiwan is currently in a cloud computing data center expansion phase. Big data access and analysis is the critical technology application for cloud computing data centers (Agrawal et al., 2011; Baer et al., 2011) and drives the development of global server and data storage market. One of the driving forces behind the current wave of growth in big data applications is the progress of cloud computing technology. Today, many enterprises and government units have begun deploying cloud services and related applications through rebuilding the data center infrastructure. The adoption of cloud computing technology by enterprise and government information systems will also facilitate the introduction of big data related software and services in the future. With these effects, global big data market is expected to achieve steady growth (IDC, 2012).

Currently, major enterprises worldwide are exploring possible opportunities in the emerging big data market (Waller and Fawcett, 2013). However, the scope, development trends, and possible strategy of big data industry have not been clearly addressed in the literature so far. To help enterprises move forward toward the emerging big data market opportunities, this research aims to address the quest for development trends and strategy planning for the big data industry. By using Taiwan's big data industry as a case study, this research attempts to define industry scope, assess business environment by SWOT analysis, forecast production value and growing trend, and outline strategy for the emerging cloud computing industry. The results can provide a practical reference for vendors interested in entering the emerging big data market.

\section{LITERATURE REVIEW}

Big data is an emerging technology for managing, analyzing, and visualizing the fast growing data encountered in firms and societies (Bollier, 2010; Bryant et al., 2008; Brown et al., 2011). Big Data Analytics (BDA) refers to a technology and framework designed to quickly store, convert, transfer, and analyze the massive amounts of constantly updated, instantly varied, structured and unstructured data for commercial and social benefit (Russom, 2011). BDA has now evolved from large database management systems to cloud services in order to process and analyze the data to make them more economical, more effective, and easier for users to manipulate (Baer, 2011; Borkar et al., 2012). Key global big data vendors today include IBM, Oracle, SAP, EMC, Teradata, and SAS. Solutions currently offered by these vendors include Data

Warehouse, Data Mining, Business Analytics, Business Intelligence, Data 
Visualization, Decision Support, Automation Interface, and the like. Innovative technologies and solutions in this field are still under rapid development (Mukherjee, 2012).

Big data has three features: volume, velocity, and variety (Russom, 2011). Most discussion in the past has focused on how to store the volume of data. Velocity and variety are crucial in competitive differentiation. Variety refers to the variety of data formats. Data can be structured data that can be sorted or non-structured data, such as pictures, music, videos, essays, and discussions. Compared to structured data, non-structured data provides a better reflection of reality for making important decisions (Adrian, 2012; Cohen et al., 2009). The other feature is velocity. In a business environment where every second counts, businesses must collect and analyze the data in a timely manner to make crucial decisions faster compared to their competitors. Examples include real-time patient bio-monitoring in the medical industry, process improvement information in the electronics manufacturing industry, and web view/click-through data in advertising and marketing. By processing these huge volumes of constantly changing information that must be processed immediately, businesses can convert the mass of seemingly useless data into economic value (McAfee and Brynjolfsson, 2012).

\section{RESEARCH METHOD}

Since big data technologies are still in the embryonic stage, this study will employ qualitative investigation methods instead of quantitative data analysis by way of nominal group technique (NGT), vendor interviews, and focus groups.

The methods are appropriate because of an insufficiency of a well-established paradigm for business strategy in big data industry. These methods aim at converging and structuring opinions from the participants until reaching a consensus or forming a pattern (Smaling, 2003; Vicsek, 2007).

\section{Nominal Group Technique}

Nominal group technique is conducted to assist the elicitation process of data analysis (Boddy, 2012; Lloyd, 2011). For this purpose, a panel of fifteen industrial experts is formed. The panel consists of $\mathrm{CEO}, \mathrm{CIO}$, and line of business managers from various domains of Taiwanese IT industry. All of the panel members are from publicly listed firms. Their business domains include System Integration (SI), Independent Software Vendor (ISV), Internet Service Provider (ISP), device manufacturer, and data center operator. These experts represent the major participants in the big data industry. The main function of the expert panel is to help assess 
development environments and derive business strategy for big data industry. In this regard, the following questions are discussed.

1. What is the scope of the big data industry?

2. With regards to this scope, what are the development environments, in terms of internal competitiveness and external influences, of Taiwan's big data industry?

3. With regards to these development environments, what is the development trend of Taiwan's big data industry in terms of production value?

4. Recognizing the internal and external development environments, what is the possible strategy for Taiwan's big data industry to extend the growing trend of production value?

\section{Vendor Interviews and Focus Groups}

This study selected representative IT firms from Taiwan as the objects of this study according to the industry scope defined by the expert panel. The selection process is based on the rank of the revenue of the firms as well as their reputation in terms of technology innovation and market visibility. The selection criteria are as follows.

1. Revenue of the firm is among the top five in its industry domain.

2. The firm has publicly announced its vision, strategy, products, or service toward big data market.

Based on these criteria, 33 Taiwanese IT firms were selected to conduct vendor interviews and focus groups. These firms are summarized in Table 1.

Table 1 Selected Cases for Vendor Interviews and Focus Groups

\begin{tabular}{lc}
\hline \multicolumn{1}{c}{ Business Domain } & Number of Firms \\
\hline Independent Software Vendor (ISV) & 7 \\
System Integrator (SI) & 9 \\
Telecom Operator & 3 \\
Server and storage device manufacture & 6 \\
Networking device manufacture & 3 \\
Mobile device manufacture & 5 \\
Total & 33 \\
\hline
\end{tabular}




\section{RESULTS}

\section{Scope of The Big Data Industry}

By considering the definition (Chen et al., 2012) and the business models (Afuah and Tucci, 2001; Chiang et al, 2012; Morris et al., 2003) of big data and analyzing the value activities (Porter, 1980; Porter, 1985; Porter, 1991) of IT vendors, the expert panel discussed the scope of the big data industry. The results of the discussion are summarized in Table 2.

Table 2 Scope of The Big Data Industry

\begin{tabular}{|c|c|c|}
\hline $\begin{array}{l}\text { Big data related } \\
\text { product and service }\end{array}$ & Main value activity & $\begin{array}{l}\text { Business model } \\
\text { and paradigm }\end{array}$ \\
\hline $\begin{array}{l}\text { Unstructured big data } \\
\text { solution }\end{array}$ & $\begin{array}{l}\text { Entry into the big data supply chain } \\
\text { through NoSQL, Hadoop and } \\
\text { MapReduce technologies. }\end{array}$ & $\begin{array}{l}\text { Amazon, Google, } \\
\text { Facebook, Yahoo }\end{array}$ \\
\hline $\begin{array}{l}\text { Structured big data } \\
\text { solution }\end{array}$ & $\begin{array}{l}\text { Entry into the big data supply chain } \\
\text { through Advanced SQL, data } \\
\text { warehousing and data mining } \\
\text { technologies. }\end{array}$ & $\begin{array}{l}\text { Oracle, SAP, EMC, } \\
\text { Teradata, SAS }\end{array}$ \\
\hline Big data IT service & $\begin{array}{l}\text { Services offered to big data solution } \\
\text { implementation through system } \\
\text { integration, application development, } \\
\text { consultancy services, and } \\
\text { value-added operations. }\end{array}$ & IBM, HP, Accenture \\
\hline $\begin{array}{l}\text { Big data infrastructure } \\
\text { equipment support }\end{array}$ & $\begin{array}{l}\text { Entry into the big data supply chain } \\
\text { through servers, storage device, } \\
\text { network communication equipment, } \\
\text { power supply, and other branded } \\
\text { products or OEM operations. }\end{array}$ & EMC, Cisco, Intel \\
\hline
\end{tabular}

\section{Development of Taiwan's Big Data Industry}

After the expert panel determined the scope of big data industry, the possible strengths, weaknesses, opportunities, and threat attributes of Taiwan's big data industry were collected from the vendor interviews and focus group sessions. These items were compiled and submitted to the expert panel for SWOT analysis (Dyson, 2004; Pickton and Wright, 1998; Weihrich, 1982). The expert panel examined these proposed items and performed a series of screenings, cross-checking, prioritizing, and consolidating. The results of the SWOT analysis are summarized in Table 3. 
Table 3 SWOT analysis of Taiwan's big data industry

\begin{tabular}{|l} 
Strengths \\
S1. Possesses both hardware and software \\
solutions and provides professional local \\
consultancy services experience.
\end{tabular}

S2. Cooperated with the global leading companies for IT services, and prices are flexible.

S3. Has the capability of autonomous manufacturing and cheap supply of big data IT devices as an important OEM center of server and storage equipment.

\begin{tabular}{|c|}
\hline Opportunities \\
\hline O1. Large-scale cloud data center continues to
\end{tabular}

O1. Large-scale cloud data center continues to expand in scale, placing orders directly to the server and storage equipment OEM industry.

O2. Enterprise data continue to grow and support the needs of storage devices.

O3. Enterprise mobile application software and services with big data needs are growing.
W1. Limited experience in the big data related business.

W2. Weak research and development (R\&D) of key software technologies such as NoSQL and business analytics.

W3. Weak in vertical know-how as well as best practice of big data.

T1. Global leading companies lead big data technologies and standards.

T2. Part of the business is replaced by emerging vendors such as Amazon and Dropbox.

T3. Industries rise in the emerging markets such as Mainland China, India, and so on.

\section{Forecast of Taiwan's big data production value}

The production value represents the total revenue of the industry, and it is a key performance index for industry development. By evaluating the forecast revenue of Taiwan's vendors in the industry and considering the business environment in the mean time, the expert panel estimates the growth rates of production value from 2014 to 2018 , concluding that Taiwan's big data production value is expected to achieve steady growth through 2018, as shown in Table 4.

Table 4 Production value of Taiwan's big data industry

\begin{tabular}{ccccccc}
\hline Year & 2013 & 2014 & 2015 & 2016 & 2017 & 2018 \\
\hline $\begin{array}{c}\text { Production Value } \\
\text { (USD Million) }\end{array}$ & 1,205 & 1,454 & 1,688 & 1,933 & 2,160 & 2,382 \\
\hline Growth Rate (\%) & - & $20.7 \%$ & $16.1 \%$ & $14.5 \%$ & $11.7 \%$ & $10.3 \%$ \\
\hline
\end{tabular}




\section{Strategy Planning of Taiwan's Big Data Industry}

Following the method for establishing TOWS strategy matrix from the SWOT analysis introduced by Weihrich (1982), the expert panel designed strategies for Taiwan's big data industry to extend the growing trend of production value. The results are summarized in Table 5.

Table 5 Strategy planning for Taiwan's big data industry

\begin{tabular}{|c|c|}
\hline Strength/Opportunity (SO) Strategy & Weakness/Opportunity (WO) Strategy \\
\hline $\begin{array}{l}\text { SO1. Develop value-added appliance for big } \\
\text { data analytics }\end{array}$ & $\begin{array}{l}\text { WO1. Develop the SaaS version of the big } \\
\text { data software for SME market }\end{array}$ \\
\hline $\begin{array}{l}\text { SO2. Strengthen enterprise innovative } \\
\text { application development and deployment }\end{array}$ & $\begin{array}{l}\text { WO2. Cooperate with the ISVs in promoting } \\
\text { the big data analytics business }\end{array}$ \\
\hline $\begin{array}{l}\text { SO3. Extend global social media related data } \\
\text { center infrastructure business }\end{array}$ & $\begin{array}{l}\text { WO3. Develop consumers' personal data } \\
\text { storage and analytics services }\end{array}$ \\
\hline Strength/Threat (ST) Strategy & Weakness/Threat (WT) Strategy \\
\hline $\begin{array}{l}\text { ST1. Strategically ally with Mainland China, } \\
\text { India, and other developing countries to } \\
\text { explore emerging markets }\end{array}$ & $\begin{array}{l}\text { WT1. Cooperate with leading foreign vendors } \\
\text { in promoting big data analytics outsourcing } \\
\text { business of emerging markets. }\end{array}$ \\
\hline $\begin{array}{l}\text { ST2. Develop customized services to leverage } \\
\text { the big data leading vendors' existing } \\
\text { customer group }\end{array}$ & $\begin{array}{l}\text { WT2. Cooperate with leading global vendors } \\
\text { in promoting the emerging business of } \\
\text { NoSQL analytics }\end{array}$ \\
\hline
\end{tabular}

\section{CONCLUSIONS}

\section{Research Findings and Contributions}

This research work aimed to determine the big data industry scope, assess big data business environment using SWOT analysis, forecast big data production value and growing trend, and outline strategy for the emerging big data industry. Highlights of research findings are summarized as follows.

1. The scope of big data industry encompasses all aspects of structured and unstructured big data solution providers, big data related IT service providers, and big data infrastructure equipment manufacturers.

2. The strengths of Taiwan's big data industry are mainly in big data related hardware and software integration, local consultancy services, and price flexibility. 
3. The major weaknesses of Taiwan's big data industry include lack of experience in big data related business and lack of $R \& D$ in innovative big data technologies.

4. The production value of Taiwan's big data industry is estimated to reach USD 1,205 million, showing a steady growing trend from year 2013 to 2018 .

5. To extend the forecasted growing trend of production value, strategic actions need to be planned for Taiwan's big data industry. Key strategic actions include collaborating with global leading vendors of innovative big data technologies, strengthening the big data infrastructure business, for example, by promoting big data appliances, and seeking opportunities in emerging market, such as mainland China.

\section{Implications for Taiwan's Big Data Industry}

Big data industry is one of the emerging smart industries that the Taiwan government is actively promoting. Currently, the Taiwan government and businesses are actively striving to develop a complete big data industry that integrates software, hardware, and application services to build the industry's capabilities. The goal is to establish a complete big data industry supply chain to serve as the bridge to international markets for entire Taiwan IT industries.

In view of this goal, the research findings above should inform both big data vendors and government agencies responsible for supporting big data industry. In particular, with a clear picture of the strengths and weaknesses, vendors and government agencies can position themselves more precisely for big data market sectors of their competitive advantage. For example, lack of R\&D in innovative big data technologies would imply that more resources should be allocated to vendor R\&D activities in innovative big data technologies, such as NoSQL analytics; however, the NoSQL solution market is currently not a suitable opportunity target for Taiwan's big data industry.

\section{Research Limitations and Future Research Suggestions}

The aim of this research was to derive the big data industry development strategy. The influence of big data technology advancement (Kobielus et al., 2011) on industry development is not discussed. As big data technology continues to progress, the Taiwanese government has drawn up big data industry development proposal to encourage Taiwan enterprises to invest in the big data technology. The policy aims to nurture the development of the big data industry and popularize big data applications. However, as research findings illustrated, lack of $R \& D$ in innovative big data technologies is a major weakness of Taiwan's big data industry. The selection of 
possible big data related technologies and the priority of developing these technologies have so far not been clearly recognized. This decision problem requires further investigation.

Another research aim was to enhance the analysis tools, such as SWOT analysis employed in this research. SWOT is a tool for gathering situational assessment data in general. However, in the case of diverse environment assessment, such as the emerging big data industry, other multi-criteria decision support tools, like AHP (Saaty and Vargas, 2001), could be integrated with SWOT to produce the quantitative values for the SWOT factors (Ho, 2008). The integrated analysis would facilitate the consolidation of data and the transformation of factors into strategy formulation.

\section{REFERENCES}

Adrian, M. (2012). Who's Who in NoSQL DBMSs. Gartner Report, G00228114.

Afuah, A. and Tucci, C. L. (2001). Internet Business Models and Strategies: Text and Cases. Boston: McGraw-Hill.

Agrawal, D., Das, S., \& Abbadi, A. (2011). Big Data and Cloud Computing: Current

State and Future Opportunities. ACM EDBT Conference, March 22-24, 2011, Uppsala, Sweden. http://dx.doi.org/10.1145/1951365.1951432

Baer, T. (2011). 2012 Trends to Watch: Big Data. Ovum Report, OI00140-041.

Baer, T., Sheina, M., and Mukherjee, S. (2011). What is big data? The big architecture. Ovum Report, OI00140-033.

Boddy, C. (2012). The Nominal Group Technique: an aid to Brainstorming ideas in research. Qualitative Market Research, 15(1), 6-18. http://dx.doi.org/10.1108/13522751211191964

Bollier, D. (2010). The Promise and Peril of Big Data. The Aspen Institute.

Borkar, V., Carey, M., \& Li, C. (2012). Inside "Big data management": Ogres, onions, or parfaits? ACM EDBT/ICDT Joint Conference, Berlin, Germany.

Brown, B., Chui, M., \& Manyika, J. (2011). Are you ready for the era of 'big data'? McKinsey Quarterly, McKinsey \& Company, Oct. 2011.

Bryant, R., Katz, R., \& Lazowska, E. (2008). Big data computing: Creating revolutionary breakthroughs in commerce, science, and society. http://www.cra.org/ccc/initiatives.

Chen, H., Chiang, R., \& Storey, V. (2012). Business Intelligence and Analytics: From Big Data to Big Impact. MIS Quarterly, 36(4),1165-88. 
Chiang, R. H. L., Goes, P. \& Stohr, E. A. (2012). Business Intelligence and Analytics Education, and Program Development: A Unique Opportunity for the Information Systems Discipline. ACM Transactions on Management Information Systems, 3(3), 12:1-12:13. http://dx.doi.org/10.1145/2361256.2361257

Cohen, J., Dolan, B., Dunlap, M., Hellerstein, J., \& Welton, C. (2009). MAD Skills: New analysis practices for big data. ACM VLDB conference, August 24-28, 2009, Lyon, France. http://dx.doi.org/10.14778/1687553.1687576

Dyson, R. G. (2004). Strategic development and SWOT analysis at the University of Warwick. European Journal of Operational Research 1(52), 631-640. http://dx.doi.org/10.1016/S0377-2217(03)00062-6

Ho, W. (2008). Integrated analytic hierarchy process and its applications - A literature review. European Journal of Operational Research, 186(1), 211-228. http://dx.doi.org/10.1016/j.ejor.2007.01.004

IDC. (2012). Worldwide Big Data Technology and Services 2012-2015 Forecast. IDC \#233485, Volume: 1, Tab: Markets.

Kobielus, K., Moore, C., Hopkins, B., \& Coyne, S. (2011). Enterprise Hadoop: The Emerging Core of Big Data. Forrester Research, October, 2011.

Lloyd, S. (2011) Applying the nominal group technique to specify the domain of a construct. Qualitative Market Research, 14(1), 105-121. http://dx.doi.org/10.1108/13522751111099346

McAfee, A., and Brynjolfsson, E. (2012). Big Data: The management revolution. Harvard Business Review, October, 1-9.

Morris, M., Schindehutte, M. and Allen, J. (2005). The entrepreneur's business model: toward a unified perspective. Journal of Business Research, 58, 726-735. http://dx.doi.org/10.1016/j.jbusres.2003.11.001

Mukherjee, S. (2012). Deploying Big Data Systems. Ovum Report, OI00140-035.

Pickton, D. W. and Wright, S. (1998). What's SWOT in strategic analysis? Strategic Change, $7(2)$, 101-109. http://dx.doi.org/10.1002/(SICI)1099-1697(199803/04)7:2\%3C101::AID-JSC332 $\% 3 \mathrm{E} 3.0 . \mathrm{CO} ; 2-6$

Porter, M. E. (1980). Competitive Strategy. New York: Free Press.

Porter, M. E. (1985). Competitive Advantage. New York: Free Press.

Porter, M. E. (1991) Towards dynamic theory of strategy. Strategic Management Journal, 12, 95-117.

Russom, P. (2011). Big Data Analytics. TDWI Research, 4th Quarter, 2011.

Saaty, T. and Vargas, L. (2001). Models, Methods, Concepts and Applications of the Analytic Hierarchy Process. Boston, MA: Kluwer Academic Publishers. 
Smaling, A. (2003). Inductive, analogical, and communicative generalization. International Journal of Qualitative Methods, 2(1).

Vicsek, L. (2007). A scheme for analyzing the results of focus groups. International Journal of Qualitative Methods, 6(4), 22-34.

Waller, M. A. and Fawcett, S. E. (2013). Data Science, Predictive Analytics, and Big Data: A Revolution That Will Transform Supply Chain Design and Management. Journal of Business Logistics, 34(2), 77-84. http://dx.doi.org/10.1111/jbl.12010

Weihrich, H. (1982). The TOWS matrix: A tool for situational analysis. Long Range Planning, 15(2), 54-66. http://dx.doi.org/10.1016/0024-6301(82)90120-0 
Contemporary Management Research 214 